\title{
Diagnosis of carcinoma of unknown primary site with the aid of simple PCR tests: a single-center experience
}

\author{
E. SUSPITSIN ${ }^{1,2}$, G. YANUS ${ }^{1,2}$, E. IMYANITOV ${ }^{1,2,3,4, *}$ \\ ${ }^{1}$ N. N. Petrov Institute of Oncology, St. Petersburg, Russia; ${ }^{2}$ St. Petersburg State Pediatric Medical University, St. Petersburg, Russia; ${ }^{3}$ I. I. Mech- \\ nikov North-Western Medical University, St. Petersburg, Russia; ${ }^{4}$ St. Petersburg State University, St. Petersburg, Russia \\ *Correspondence: evgeny@imyanitov.spb.ru
}

Received April 23, 2017 / Accepted August 16, 2017

\begin{abstract}
This study aimed to incorporate PCR testing in the determination of organ/tissue origin for cancers of unknown primary site (CUP). We developed a PCR panel consisting of 7 expression markers (CDX2, CDH17, SPB, UGRP, MAM, LPB, TG) and 2 genes frequently mutated in cancer (KRAS and BRAF). The expression assays were intentionally interpreted in a non-quantitative way, i.e. PCR tests classified tumors either as positive or negative expressors. While applying these tests to 135 cancers belonging to 8 common types of adenocarcinomas (AdCa), we observed that this panel was capable of clearly discriminating between gastrointestinal vs. female reproductive tract vs. lung vs. thyroid tumors in $112(83 \%)$ of these cases and provided suggestive clues to correct diagnosis in $20(15 \%)$ instances. We further assessed the performance of this panel coupled with the occasional use of 2 additional mutation tests (somatic: EGFR; germ-line: BRCA1) in the real diagnostic setting. The PCR analysis of 20 consecutive CUP with known IHC status turned out to be clinically useful in 19 (95\%) cases, with $16(80 \%)$ instances of resolving the existing controversy and $3(15 \%)$ cases of providing valuable confirmation of suspected diagnosis. PCR testing of 20 consecutive CUP with unknown IHC status succeeded in establishing tumor organ/ tissue origin in $15(75 \%)$ instances and provided suggestive clues to the diagnosis in $3(15 \%)$ patients. We conclude that simple non-expensive laboratory-developed PCR assays may aid CUP diagnosis in a significant proportion of cases.
\end{abstract}

Key words: carcinomas of unknown primary site, PCR, expression, mutation

Carcinomas of unknown primary site (CUP) account for $2-5 \%$ of cancer incidence [1-5]. Many failures to determine the organ and/or tissue of origin of malignant disease are attributed solely to diagnostic limitations. However, a significant share of CUP cases remains unresolved even upon autopsy $[2,3,6]$. It is assumed that certain patients may manifest with metastatic disease in the absence of a detectable primary tumor site, given that the spread of malignant clones may not necessarily require the initial organ settlement of cancer-originating cells, as well as accounting for rare but still well-documented cases of regression of primary tumor lumps [7, 8]. Overall, CUP have a worse prognosis as compared to tumors with definite diagnosis, due to their intrinsic biological aggressiveness and difficulties in defining the optimal treatment strategy [3]. Correct determination of the tissue of origin for CUP may result in the change of the therapeutic scheme and improved treatment outcome at least in a subset of cases $[5,9-12]$.

Current algorithms of CUP laboratory diagnosis largely rely on immunohistochemical (IHC) staining for tissue- specific markers. This approach has some limitations, given the restricted spectrum of available diagnostic antibodies, significant interlaboratory and interobserver variability of some IHC assays, lack of automation, need for a relatively high amount of tissue for multiple IHC testing, etc. [3-5, 12-14]. Introduction of DNA- and RNA-based tumor/ tissue-specific markers opened opportunities for improved CUP diagnosis $[10,12,13]$. Some cancer-specific mutations demonstrate very high level of specificity: for example, EGFR gene lesions occur in $10-20 \%$ and $20-76 \%$ lung adenocarcinomas (AdCa) in non-Asians and Asians, respectively [15, 16], while being exceptionally uncommon in other tumor types [17]. In specific circumstances, even germ-line testing may be of some value: for instance, BRCA1 heterozygous mutations can be found in approximately $5 \%$ of breast and $15 \%$ of ovarian AdCa, while the probability of finding this genetic defect in a patient with BRCA1-non-related cancer type is very low [18-20]. PCR is able to reveal residual amounts of the transcripts in the tumor cells; therefore, in contrast to IHC, PCR actually does not have a sensitivity 
threshold. Furthermore, a PCR test can be developed within a reasonable amount of time virtually for any RNA message, while obtaining the diagnostic antibody to a given protein is significantly more challenging. Finally, current format of real-time PCR allows more automated and user-independent assessment of the testing results as compared to conventional IHC, and PCR requires only a minuscule amount of cancer tissue for dozens of reactions.

There are several commercial assays for CUP molecular profiling, which involve a high number of analyzed genes, use sophisticated algorithms for data analysis and may not be easily accessible in some countries due to high costs [3, $12,13]$. Here, we integrated several expression and mutation markers into a single laboratory-developed assay and evaluated its performance in cancers of known and unknown origin. We show that in many circumstances this potentially reproducible and inexpensive PCR analysis helps to reveal organ/tissue identity for tumor disease.

\section{Materials and methods}

Formalin-fixed paraffin-embedded tumor blocks were utilized both for expression and mutation analysis. DNA and RNA extraction was performed by a single laboratory procedure, and RNA was converted to cDNA by the reverse transcription [21]. Briefly, 2-3 $20 \mu \mathrm{m}$-thick sections of the tumor-containing areas of the tissue block were deparaffinized in 2 changes of xylene, rinsed by $96 \%$ and $70 \%$ ethanol, air-dried and then incubated for 6 hours in $200 \mu \mathrm{l}$ of lysis buffer (10 mM Tris- $\mathrm{HCl}$ ( $\mathrm{pH} 8.0), 0.1 \mathrm{mM}$ EDTA (pH 8.0), 2\% SDS, $500 \mu \mathrm{g} / \mathrm{ml}$ proteinase $\mathrm{K}$ ) at $60^{\circ} \mathrm{C}$. These lysates were subjected to organic extraction using equal volume of the Trizol reagent (Life Technologies, Carlsbad, CA) and 0.5 volume of chloroform. Second round of extraction was done with 0.5 volume of chloroform. DNA and RNA were precipitated by the addition of 2 volumes of ethanol, 0.1 volume of $3 \mathrm{M}$ sodium acetate and glycogen carrier up to $0.1 \mu \mathrm{g} / \mu \mathrm{l}$, pelleted by centrifugation and dissolved in $10 \mu \mathrm{l}$ of water. The entire DNA/RNA samples were placed in the tube for reverse transcription, which contained 100 pmol random hexamer primers, $4 \mu \mathrm{l} 5$-x reaction buffer, $0.5 \mu \mathrm{l}$ RiboLock RNAse inhibitor, $2 \mu \mathrm{ldNTPmix}$ (10 mM each), and $200 \mathrm{U}$ RevertAid reverse transcriptase (Thermo Fisher Scientific) in a total volume of $20 \mu \mathrm{l}$. This mix was incubated at $25^{\circ} \mathrm{C}$ for $10 \mathrm{~min}$ and then at $42^{\circ} \mathrm{C}$ for 1 hour; the reaction was stopped by heating at $70^{\circ} \mathrm{C}$ for $10 \mathrm{~min}$. This mixture of cDNA and genomic DNA served as a template both for expression analysis and analysis of mutations [21]. It is essential to realize that the presence of genomic DNA does not compromise the analysis of RNA expression, as the transcript-specific primers are located in neighboring exons of the studied gene; being separated by an intron, they usually cannot amplify the product from the genomic DNA template. Vice versa, the presence of cDNA does not compromise the analysis of mutations given that they are present both in genomic DNA and corresponding RNA transcripts.

Table 1. Tissue/tumor-specific markers for analysis of adenocarcinomas of unknown primary site*.

\begin{tabular}{|c|c|c|c|c|c|}
\hline Gene symbol/aliases & Gene name(s) & $\begin{array}{c}\text { Organ/tissue } \\
\text { specificity }\end{array}$ & References & Primer pairs & $\begin{array}{l}\text { Product size, } \\
\text { bp }\end{array}$ \\
\hline \multicolumn{6}{|c|}{ Tissue-specific expression markers } \\
\hline $\mathrm{CDX} 2$ & Caudal type homeobox type 2 & $\begin{array}{l}\text { Gastrointestinal } \\
\text { tract }\end{array}$ & {$[27,28]$} & $\begin{array}{l}\text { 5'-GCGGAACCTGTGCGAGTG-3' } \\
\text { 5'-GCCGCTGGTGGTCCGTG-3' }\end{array}$ & 110 \\
\hline CDH17 (HPT1) & Cadherin 17 & $\begin{array}{l}\text { Gastrointestinal } \\
\text { tract }\end{array}$ & {$[29-31]$} & $\begin{array}{l}\text { 5'-TGAAGGCCAAGAACCGAGTC-3' } \\
\text { 5'-TCTGTCTCCCCAGTTAGTTC-3' }\end{array}$ & 84 \\
\hline $\begin{array}{l}\text { MAM } \\
\text { (SCGB2A2; MGB1) }\end{array}$ & $\begin{array}{l}\text { Mammoglobin; secretoglobin } \\
\text { family } 2 \text { A member } 2\end{array}$ & Breast & {$[31-34]$} & $\begin{array}{l}\text { 5'-GAAGTTGCTGATGGTCCTCA-3' } \\
\text { 5'-GTCTTAGACACTTGTGGATTG-3' }\end{array}$ & 117 \\
\hline LPB (SCGB1D2; LIPB) & $\begin{array}{l}\text { Lipophilin B; secretoglobin } \\
\text { family } 1 \mathrm{D} \text { member } 2\end{array}$ & $\begin{array}{l}\text { Endometrium, } \\
\text { breast }\end{array}$ & {$[33]$} & $\begin{array}{l}\text { 5'-GGTGTGTCTCCTGCTGGTC-3' } \\
\text { 5'-AAGAAGAAGTCTAACAGCTCAG-3' }\end{array}$ & 96 \\
\hline SPB (SFTPB) & Surfactant protein B & Lung & {$[31,35]$} & $\begin{array}{l}\text { 5'-TCAAGCGGATCCAAGCCATG-3' } \\
\text { 5'-TAGCGCTCAGCCAGGCAC-3' }\end{array}$ & 115 \\
\hline $\begin{array}{l}\text { UGRP (UGRP1; SC- } \\
\text { GB3A2) }\end{array}$ & $\begin{array}{l}\text { Uteroglobin-related protein } 1 \text {; } \\
\text { secretoglobin family } 3 \mathrm{~A} \\
\text { member } 2\end{array}$ & Lung & [36] & $\begin{array}{l}\text { 5'-GTCATGAAGCTGGTAACTATC-3' } \\
\text { 5'-AGGTGCCAACTTGTCAACAG-3' }\end{array}$ & 111 \\
\hline TG & Thyroglobulin & Thyroid & {$[28]$} & $\begin{array}{l}\text { 5'-GGGAGAGTTTATGCCTGTC-3' } \\
\text { 5'-GGAAGGAACTGAAGGTCAC-3' }\end{array}$ & 116 \\
\hline \multicolumn{6}{|c|}{ Ubiquitously expressed gene (PCR control) } \\
\hline SDHA & $\begin{array}{l}\text { Succinate dehydrogenase com- } \\
\text { plex flavoprotein subunit A }\end{array}$ & & {$[37]$} & $\begin{array}{l}\text { 5'-CСАCTCGCTATTGCACACC-3' } \\
\text { 5'-CACTCCCСGTTCTCCATCA-3' }\end{array}$ & 102 \\
\hline
\end{tabular}

${ }^{*}$ References correspond to the studies, which demonstrated the organ-specific pattern of expression of the mentioned genes; CDH17, SPB and mammoglobin markers were also utilized in the commercial Veridex CUP assay [31]. Primer sequences presented in the Table were designed specifically for this study and validated by gel-electrophoresis; PCR conditions for KRAS, BRAF, EGFR and BRCA1 mutation testing were described in [21-23]. 
The expression analysis utilized standard PCR conditions: $1 \mu \mathrm{l}$ cDNA template (approximately 25-50 ng), 0.5 units hot-start Taq polymerase, $1 \mu \mathrm{l} 10$-x PCR buffer ( $\mathrm{pH} 8.3$ ), $1.5 \mathrm{mM} \mathrm{MgCl}_{2}, 200 \mu \mathrm{M}$ dNTPs, $0.3 \mu \mathrm{M}$ primers, $1 \mu \mathrm{l} 2$-x SYBR Green I in a total volume of $10 \mu \mathrm{l}$. SDHA gene transcript was used as a control. Primer sequences for tumor/tissue-specific markers are given in Table 1. PCR reactions started from the activation of Taq polymerase $\left(10 \mathrm{~min}, 95^{\circ} \mathrm{C}\right)$ and proceeded for 45 cycles (denaturation: $15 \mathrm{~s}, 95^{\circ} \mathrm{C}$; annealing: $30 \mathrm{~s} ; 60^{\circ} \mathrm{C}$; synthesis: $30 \mathrm{~s}, 72^{\circ} \mathrm{C}$ ); each reaction was completed by a final extension step $\left(5 \mathrm{~min}, 72^{\circ} \mathrm{C}\right)$. To ensure the specificity of PCR amplification, all expression assays were initially validated by the visualization of PCR products in $10 \%$ polyacrylamide gel. The routine detection of tumor RNA markers was based on the analysis of amplification curves generated by the CFX96 PCR instrument (BioRad). PCR expression assays, which resulted in accumulation of detectable gene-specific product, were considered positive irrespective of the amount of the latter; the remaining tests were classified as negative. KRAS and BRAF mutations were analyzed as described in [22]. Whenever appropriate, testing for somatic mutations in EGFR gene and founder germ-line mutations in BRCA1 gene was applied [21,23].

\section{Results}

The performance of the PCR panel consisting of 7 expression (CDX2, CDH17, SPB, UGRP, MAM, LPB, TG) and 2 mutation (KRAS, BRAF) markers was evaluated in 135 tumors belonging to 8 types of AdCa with known organ origin (Table 2). Some of the markers and/or their combinations produced reasonable diagnostic value. For example, all colorectal tumors were positive for CDX2 and CDH17, all lung AdCa expressed either SPB or UGRP, all breast cancers produced either MAM or LPB, and all thyroid cancers were positive for TG (Tables 2,3). Some of the markers had remarkable negative value: for instance, none of the non-lung AdCa was positive both for SPB and UGRP, and lack of detectable expression of MAM was characteristic for tumors arising outside the female genital tract. As expected, the discrimination between the tumors of distinct histological origin (gastrointestinal vs. female reproductive tract vs. lung vs. thyroid) looked more achievable than for AdCa having similar histogenesis; for instance, our set of markers could not reliably distinguish between colon, stomach and pancreatic cancer, nor they were able to discriminate between breast, ovarian or endometrial tumors (Table 2).

Table 2. Analysis of tissue/tumor-specific markers in major types of adenocarcinomas.

\begin{tabular}{|c|c|c|c|c|c|c|c|c|c|c|c|c|c|c|c|}
\hline \multirow[b]{3}{*}{ Tumor type } & \multicolumn{13}{|c|}{ Expression markers } & \multicolumn{2}{|c|}{ Mutations } \\
\hline & \multicolumn{4}{|c|}{ Gastrointestinal markers } & \multicolumn{4}{|c|}{ Female reproductive tract } & \multicolumn{4}{|c|}{ Lung } & \multirow{2}{*}{ Thyroid } & & \\
\hline & ชี & $\vec{\theta}$ & 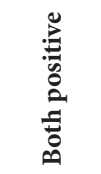 & 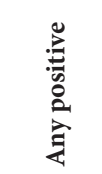 & $\sum_{\sum}$ & : & 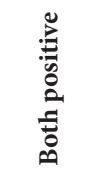 & 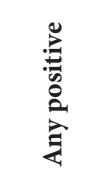 & 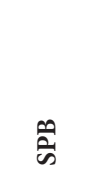 & 荧 & 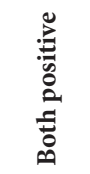 & 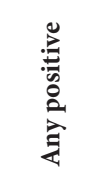 & & 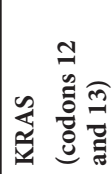 & 焉 \\
\hline $\begin{array}{l}\text { Lung, } \\
\mathrm{n}=13\end{array}$ & 0 & $\begin{array}{c}2 \\
(15 \%)\end{array}$ & 0 & $\begin{array}{c}2 \\
(15 \%)\end{array}$ & 0 & 0 & 0 & 0 & $\begin{array}{c}12 \\
(92 \%)\end{array}$ & $\begin{array}{c}10 \\
(77 \%)\end{array}$ & $\begin{array}{c}9 \\
(69 \%)\end{array}$ & $\begin{array}{c}13 \\
(100 \%)\end{array}$ & 0 & $\begin{array}{c}5 \\
(38 \%)\end{array}$ & 0 \\
\hline $\begin{array}{l}\text { Colorectal, } \\
\mathrm{n}=11\end{array}$ & $\begin{array}{c}11 \\
(100 \%)\end{array}$ & $\begin{array}{c}11 \\
(100 \%)\end{array}$ & $\begin{array}{c}11 \\
(100 \%)\end{array}$ & $\begin{array}{c}11 \\
(100 \%)\end{array}$ & 0 & 0 & 0 & 0 & 0 & 0 & 0 & 0 & $\begin{array}{c}2 \\
(18 \%)\end{array}$ & $\begin{array}{c}4 \\
(36 \%)\end{array}$ & \\
\hline $\begin{array}{l}\text { Stomach, } \\
\mathrm{n}=19\end{array}$ & $\begin{array}{c}11 \\
(55 \%)\end{array}$ & $\begin{array}{c}14 \\
(70 \%)\end{array}$ & $\begin{array}{c}10 \\
(53 \%)\end{array}$ & $\begin{array}{c}15 \\
(79 \%)\end{array}$ & 0 & $\begin{array}{c}1 \\
(5 \%)\end{array}$ & 0 & $\begin{array}{c}1 \\
(5 \%)\end{array}$ & 0 & 0 & 0 & 0 & $\begin{array}{c}2 \\
(11 \%)\end{array}$ & $\begin{array}{c}1 \\
(5 \%)\end{array}$ & $\begin{array}{c}1 \\
(5 \%)\end{array}$ \\
\hline $\begin{array}{l}\text { Pancreas, } \\
\mathrm{n}=15\end{array}$ & $\begin{array}{c}7 \\
(47 \%)\end{array}$ & $\begin{array}{c}10 \\
(67 \%)\end{array}$ & $\begin{array}{c}4 \\
(27 \%)\end{array}$ & $\begin{array}{c}13 \\
(87 \%)\end{array}$ & 0 & $\begin{array}{c}1 \\
(7 \%)\end{array}$ & 0 & $\begin{array}{c}1 \\
(7 \%)\end{array}$ & $\begin{array}{c}2 \\
(13 \%)\end{array}$ & 0 & 0 & $\begin{array}{c}2 \\
(13 \%)\end{array}$ & $\begin{array}{c}3 \\
(20 \%)\end{array}$ & $\begin{array}{c}8 \\
(53 \%)\end{array}$ & 0 \\
\hline $\begin{array}{l}\text { Breast, } \\
n=26\end{array}$ & 0 & $\begin{array}{c}2 \\
(8 \%)\end{array}$ & 0 & $\begin{array}{c}2 \\
(8 \%)\end{array}$ & $\begin{array}{c}23 \\
(89 \%)\end{array}$ & $\begin{array}{c}25 \\
(96 \%)\end{array}$ & $\begin{array}{c}21 \\
(81 \%)\end{array}$ & $\begin{array}{c}26 \\
(100 \%)\end{array}$ & $\begin{array}{c}2 \\
(8 \%)\end{array}$ & $\begin{array}{c}2 \\
(8 \%)\end{array}$ & 0 & $\begin{array}{c}4 \\
(15 \%)\end{array}$ & $\begin{array}{c}7 \\
(27 \%)\end{array}$ & $\begin{array}{c}1 \\
(4 \%)\end{array}$ & 0 \\
\hline $\begin{array}{l}\text { Ovary, } \\
\mathrm{n}=19\end{array}$ & $\begin{array}{c}2 \\
(11 \%)\end{array}$ & $\begin{array}{c}2 \\
(11 \%)\end{array}$ & 0 & $\begin{array}{c}4 \\
(21 \%)\end{array}$ & $\begin{array}{c}6 \\
(32 \%)\end{array}$ & $\begin{array}{c}13 \\
(68 \%)\end{array}$ & $\begin{array}{c}5 \\
(26 \%)\end{array}$ & $\begin{array}{c}14 \\
(74 \%)\end{array}$ & & 0 & 0 & 0 & $\begin{array}{c}2 \\
(11 \%)\end{array}$ & 0 & $\begin{array}{c}1 \\
(5 \%)\end{array}$ \\
\hline $\begin{array}{l}\text { Endometrial, } \\
\mathrm{n}=13\end{array}$ & $\begin{array}{c}2 \\
(15 \%)\end{array}$ & $\begin{array}{c}3 \\
(23 \%)\end{array}$ & $\begin{array}{c}2 \\
(15 \%)\end{array}$ & $\begin{array}{c}3 \\
(23 \%)\end{array}$ & $\begin{array}{c}1 \\
(8 \%)\end{array}$ & $\begin{array}{c}5 \\
(39 \%)\end{array}$ & 0 & $\begin{array}{c}6 \\
(46 \%)\end{array}$ & 0 & 0 & 0 & 0 & 0 & 0 & 0 \\
\hline $\begin{array}{l}\text { Thyroid, } \\
\mathrm{n}=19\end{array}$ & 0 & $\begin{array}{c}2 \\
(11 \%)\end{array}$ & 0 & $\begin{array}{c}2 \\
(11 \%)\end{array}$ & 0 & $\begin{array}{c}4 \\
(21 \%)\end{array}$ & 0 & $\begin{array}{c}4 \\
(21 \%)\end{array}$ & $\begin{array}{c}13 \\
(68 \%)\end{array}$ & 0 & 0 & $\begin{array}{c}13 \\
(68 \%)\end{array}$ & $\begin{array}{c}19 \\
(100 \%)\end{array}$ & $\begin{array}{c}2 \\
(11 \%)\end{array}$ & $\begin{array}{c}5 \\
26 \%)\end{array}$ \\
\hline Specificity & $95.6 \%$ & $87.8 \%$ & $97.7 \%$ & $85.5 \%$ & $100 \%$ & $92.2 \%$ & $100 \%$ & $92.2 \%$ & $86.1 \%$ & $98.4 \%$ & $100 \%$ & $84.4 \%$ & $86.2 \%$ & na & na \\
\hline Sensitivity & $64.4 \%$ & $77.8 \%$ & $55.5 \%$ & $86.7 \%$ & $51.7 \%$ & $63 \%$ & $44.8 \%$ & $79.3 \%$ & $92.3 \%$ & $76.9 \%$ & $69.2 \%$ & $100 \%$ & $100 \%$ & na & na \\
\hline
\end{tabular}


Table 3. Typical distribution of tissue/tumor-specific expression markers in major types of adenocarcinomas.

\begin{tabular}{lccc}
\hline Tumor types & Always/often positive & Always negative & Optional \\
\hline Lung, $\mathrm{n}=13$ & SPB and/or UGRP & CDX2, Mam, LPB, TG & CDH17 \\
Colorectal, $\mathrm{n}=11$ & CDX2 and/or CDH17 & Mam, LPB, SPB, UGRP & TG \\
Stomach, $\mathrm{n}=19$ & CDX2 and/or CDH17 & Mam, SPB, UGRP & TG, LPB; negativity for all markers \\
Pancreas, $\mathrm{n}=15$ & CDX2 and/or CDH17 & Mam, UGRP & TG, LPB,SPB \\
Breast, $\mathrm{n}=26$ & MAM and/or LPB & CDX2 & SPB, UGRP, TG \\
Ovary, $\mathrm{n}=19$ & MAM and/or LPB & SPB, UGRP & CDX2, CDH17, TG; negativity for all markers \\
Endometrial, $\mathrm{n}=13$ & MAM and/or LPB & SPB, UGRP, TG & CDX2, CDH17, TG; negativity for all markers \\
Thyroid, $\mathrm{n}=19$ & TG & CDX2, MAM, UGRP & CDH17, SPB, LPB \\
\hline
\end{tabular}

To our knowledge, there is no known single-gene markers capable of overcoming this limitation [1-7, 10-14]. Some of the markers appeared to be less informative than previously reported [24]: for example, almost a half of pancreatic tumors lacked KRAS mutation.

When we analyzed tumors by histological groups on a case-by-case basis (Table 4), 38/45 (84\%) gastrointestinal cancers had distribution of markers highly consistent with their origin, 4/45 (9\%) shared some expression characteristics with ovarian/endometrial cancers, 3/45 (7\%) could be wrongly classified as thyroid $(n=2)$ or lung $(n=1)$ carcinomas. Among cancers of female reproductive tract, 42/58 (72\%) had distribution of markers perfectly fitting their origin, and $16 / 58$ (28\%) revealed expression pattern that can occur both in ovarian/endometrial and stomach cancer. In contrast to the above groups, all lung $(13 / 13,100 \%)$ and thyroid $(19 / 19,100 \%)$ cancers showed clearly organ-specific pattern of molecular markers. Overall, the proposed panel of PCR tests provided definite data on histological origin of the tumors in 112/135 (83\%) cases, offered ambivalent results for $20 / 135$ (15\%) tumors, and resulted in potentially wrong diagnosis in 3/135 (2\%) AdCa.

We further applied these PCR assays to the consecutive patients, whose tumor material was forwarded to the laboratory analysis between years 2010 and 2015 with the aim of establishing tissue/organ origin of CUP. The choice of PCR markers for each tumor case was made on an individual basis, and depended on clinical circumstances and gender of the patients. The first group of samples $(n=20)$ included patients, who underwent comprehensive single-center testing in the N. N. Petrov Institute of Oncology (St. Petersburg), and therefore had exhaustive clinical and IHC data (Supplementary Table 1). In these patients, molecular testing appeared helpful in 19/20 (95\%) cases, with 16 instances where molecular analysis succeeded to resolve controversial diagnosis, and 3 cases where PCR testing appeared to be capable to provide correct information irrespectively to other procedures. The second group of samples $(n=20)$ arrived to PCR testing without complete accompanying information, e.g. IHC data, therefore the analysis of these cases was performed in a more independent manner (Supplementary Table 2). The molecular analysis turned out to be useful in $18 / 20$ patients from this group, with 15 instances of plausible identification of organ/tissue origin of the tumor and 3 cases of apparently helpful suggestive evidence.

\section{Discussion}

Estimation of performance of CUP diagnostic tests is, by definition, compromised by several factors [11]. In some instances, the true organ of origin for CUP can be established during patients' follow-up, up to postmortem examination [25]. However, in the real clinical setting many patients are usually lost from follow-up, and even autopsy fails to clarify the diagnosis for $15-45 \%$ of CUP cases $[1,2,6]$. An alternative way of the data interpretation relies on the compatibility of markers' distribution with the profiles of tumors of known origin and/or supporting IHC and clinical data. This approach is based on a relative stability of expression of tissue-specific markers [13]; it neglects the instances of impressive plasticity of tumor cells, which are sometimes capable to entirely change their phenotypic appearance [26].

There is a number of standard CUP molecular assays, although only a few of them continue to be marketed (Table 5). Despite some earlier expectations, the diagnosis of CUP remains to be largely done on the case-by-case basis [13], which is attributed both to the thoughtful clinical attitudes and to the desire to avoid unnecessary expenses. Here we developed several simple, easily interpretable PCR expression assays as well as invoked to the CUP diagnosis a few already available mutation tests. We demonstrate that this genetic testing, being non-expensive while relying on the laboratory-developed protocols, may add significant information to the available clinical and IHC data, and even have an independent diagnostic value in some circumstances. Both IHC- and PCR-based CUP molecular profiling techniques have some advantages and limitations, therefore they can be used both interchangeably and in combination (Table 6).

This study has some notable limitations. The interlaboratory reproducibility of "in-house" PCR assays continues to be questioned. Furthermore, our PCR panel covered only a limited spectrum of AdCa types, while some of the existing commercial tests consider higher number of tumor varieties. 
Table 4. Expression patterns of adenocarcinomas with known organ origin.

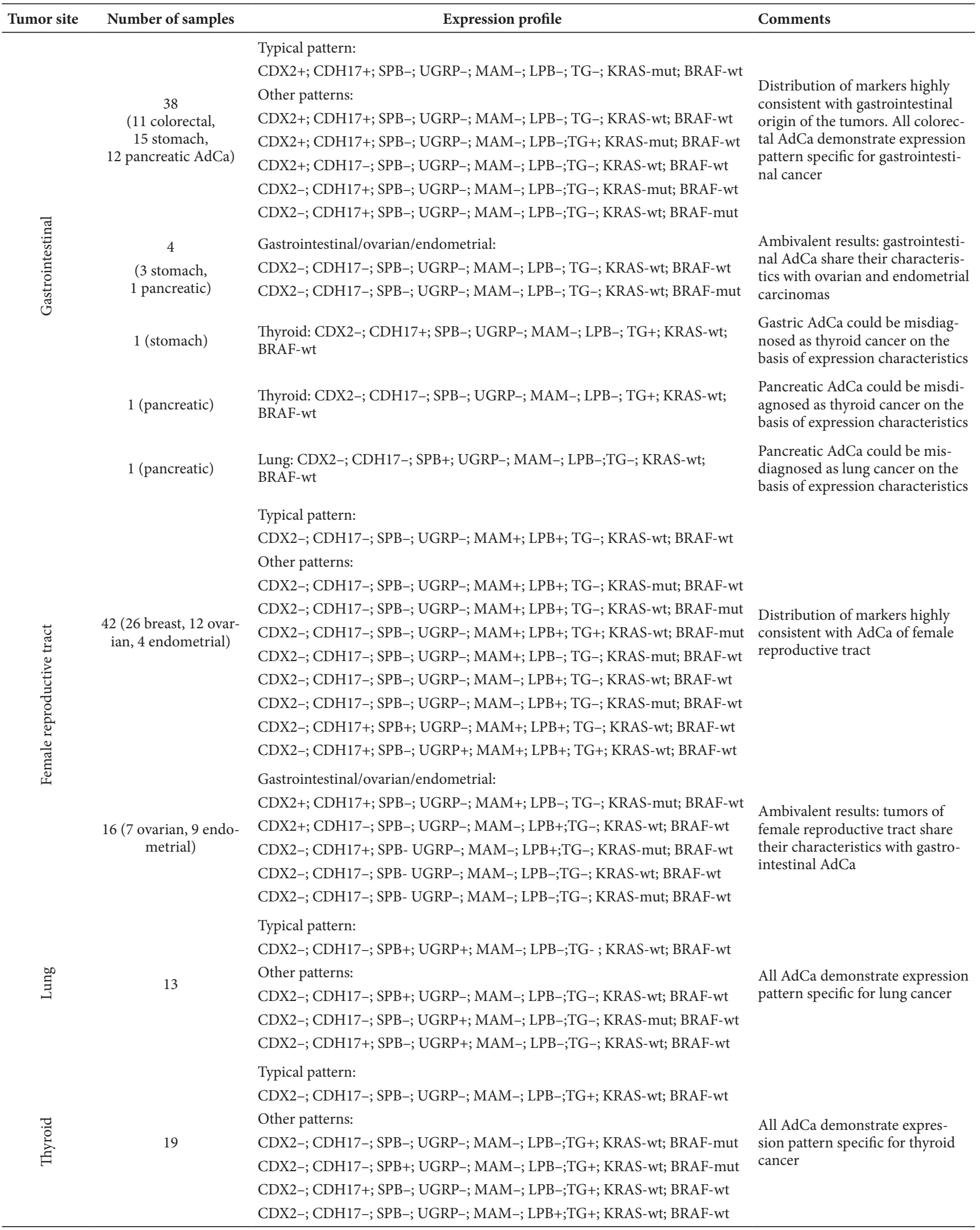


Table 5. Available commercial tests for CUP molecular profiling.

\begin{tabular}{|c|c|c|c|c|c|}
\hline Test name* & Company & Method & $\begin{array}{c}\text { Number of } \\
\text { genes analyzed }\end{array}$ & $\begin{array}{l}\text { Number of tumor } \\
\text { types detected }\end{array}$ & Reference \\
\hline CancerTypeID & Biotheranostics & Real-time PCR & 92 & $\begin{array}{l}50 \text { (including } \\
\text { subtypes) }\end{array}$ & www.cancertypeid.com \\
\hline $\begin{array}{l}\text { Tissue of Origin test (formerly } \\
\text { Pathwork test) }\end{array}$ & $\begin{array}{l}\text { Cancer Genetics } \\
\text { Inc. }\end{array}$ & cDNA microarray & 2000 & 15 (58 subtypes) & $\begin{array}{l}\text { www.cancergenetics.com/ } \\
\text { laboratory-services/specialty- } \\
\text { tests/too-tissue-of-origin-test/ }\end{array}$ \\
\hline $\begin{array}{l}\text { Rosetta Gx Cancer Origin } \\
\text { (formerly miRview } ® \text { mets } 2 \text { ) }\end{array}$ & $\begin{array}{c}\text { Rosetta } \\
\text { Genomics }\end{array}$ & miRNA microarray & 64 & 49 & $\begin{array}{l}\text { https://rosettagx.com/testing- } \\
\text { services/cancer-origin }\end{array}$ \\
\hline
\end{tabular}

*There is a number of commercial tests which were repeatedly mentioned in the literature, but are not marketed for the time being [3, 38, 39].

Table 6. PCR and IHC for CUP diagnosis: advantages and limitations.

\begin{tabular}{lll}
\hline Method & Advantages & Limitations \\
\hline IHC & Compatible with infrastructure of standard pathology laboratory & $\begin{array}{l}\text { Spectrum of tissue-specific markers is limited by available commer- } \\
\text { cial antibodies } \\
\end{array}$ \\
$\begin{array}{l}\text { Provides information on subcellular distribution of the marker } \\
\text { staining }\end{array}$ & $\begin{array}{l}\text { Low potential for automation, limited throughput } \\
\end{array}$ & Substantial interlaboratory variations \\
& & Limited sensitivity
\end{tabular}

High spectrum of markers (laboratory-developed assays can be designed for any gene-specific transcript)

PCR High potential for automation

Very high sensitivity, requires only a tiny amount of material

Suitable for both expression assays and analysis of mutations

Very low cost for home-made tests

Requires personnel trained in molecular biology

Unable to detect posttranslational protein modifications
In addition, we did not have a follow-up data for the majority of the patients analyzed, therefore it is not definitely known whether the PCR-based diagnosis turned out to be eventually correct, and whether it indeed helped to manage the patients. Future activities may require further adjustment of the spectrum of tissue/tumor-specific PCR markers and multicenter assessment of the accuracy of this approach.

In summary, this study suggests a PCR-based test, which combines several highly-informative genetic markers and is capable to determine the organ/tissue origin of adenocarcinoma of unknown primary site. It provides some update as compared to published PCR CUP assays, as it considers several organ-specific mutations in addition to expression characteristics of the tumors. When assessed against IHC, PCR detection of DNA/RNA markers is likely to be more flexible, reproducible and amenable to automation. Contrary to available commercial CUP tests, the suggested assay does not require sophisticated computational analysis of multigene expression data, but relies on an intuitively logical, straightforward and transparent approach to the tumor categorization. Low cost is an essential advantage of this laboratory-developed protocol. We believe that consideration of such simple home-made assays may facilitate the diagnosis of carcinomas of unknown primary site and decrease the related expenses.
Acknowledgments: This work was supported by the Russian Scientific Fund (grant 15-15-00079). We cordially thank Gloria Daffner for her help in the English editing of this manuscript.

\section{References}

[1] PAVLIDIS N, FIZAZI K. Carcinoma of unknown primary (CUP). Crit Rev Oncol Hematol 2009; 69: 271-278. https:// doi.org/10.1016/j.critrevonc.2008.09.005

[2] MASSARD C, LORIOT Y, FIZAZI K. Carcinomas of an unknown primary origin-diagnosis and treatment. Nat Rev Clin Oncol 2011; 8: 701-710. https://doi.org/10.1038/nrclinonc.2011.158

[3] DOLLED-FILHART MP, RIMM DL. Gene expression array analysis to determine tissue of origin of carcinoma of unknown primary: cutting edge or already obsolete? Cancer Cytopathol 2013; 121: 129-135. https://doi.org/10.1002/ cncy. 21228

[4] PAVLIDIS N, PENTHEROUDAKIS G. Cancer of unknown primary site. Lancet 2012; 379: 1428-1435. https://doi. org/10.1016/S0140-6736(11)61178-1

[5] FIZAZI K, GRECO FA, PAVLIDIS N, DAUGAARD G, OIEN $\mathrm{K}$ et al. Cancers of unknown primary site: ESMO Clinical Practice Guidelines for diagnosis, treatment and follow-up. Ann Oncol 2015; 26 Suppl 5: v133-138. https:// doi.org/10.1093/annonc/mdv305 
[6] GRECO FA, OIEN K, ERLANDER M, OSBORNE R, VARADHACHARY $G$ et al. Cancer of unknown primary: progress in the search for improved and rapid diagnosis leading toward superior patient outcomes. Ann Oncol 2012; 23: 298-304. https://doi.org/10.1093/annonc/mdr306

[7] PENTHEROUDAKIS G, BRIASOULIS E, PAVLIDIS N. Cancer of unknown primary site: missing primary or missing biology? Oncologist 2007; 12: 418-425. https://doi. org/10.1634/theoncologist.12-4-418

[8] KAMPOSIORAS K, PENTHEROUDAKIS G, PECTASIDES D, PAVLIDIS N. Malignant melanoma of unknown primary site. To make the long story short. A systematic review of the literature. Crit Rev Oncol Hematol 2011; 78: 112-126. https://doi.org/10.1016/j.critrevonc.2010.04.007

[9] HAINSWORTH JD, RUBIN MS, SPIGEL DR, BOCCIA RV, RABY S et al. Molecular gene expression profiling to predict the tissue of origin and direct site-specific therapy in patients with carcinoma of unknown primary site: a prospective trial of the Sarah Cannon research institute. J Clin Oncol 2013; 31: 217-223. https://doi.org/10.1200/JCO.2012.43.3755

[10] HAINSWORTH JD, GRECO FA. Gene expression profiling in patients with carcinoma of unknown primary site: from translational research to standard of care. Virchows Arch 2014; 464: 393-402. https://doi.org/10.1007/s00428-014-1545-2

[11] VARADHACHARY GR, RABER MN. Cancer of unknown primary site. N Engl J Med 2014; 371: 757-765. https://doi. org/10.1056/NEJMra1303917

[12] ECONOMOPOULOU P, MOUNTZIOS G, PAVLIDIS $\mathrm{N}$, PENTHEROUDAKIS G. Cancer of Unknown Primary origin in the genomic era: elucidating the dark box of cancer. Cancer Treat Rev 2015; 41: 598-604. https://doi. org/10.1016/j.ctrv.2015.05.010

[13] OIEN KA, DENNIS JL. Diagnostic work-up of carcinoma of unknown primary: from immunohistochemistry to molecular profiling. Ann Oncol 2012; 10: x271-x277. https://doi. org/10.1093/annonc/mds357

[14] GRECO FA. Cancer of unknown primary site: improved patient management with molecular and immunohistochemical diagnosis. Am Soc Clin Oncol Educ Book 2013; 175-181. https://doi.org/10.1200/EdBook_AM.2013.33.175

[15] MOISEYENKO VM, PROCENKO SA, LEVCHENKO EV, BARCHUK AS, MOISEYENKO FV et al. High efficacy of first-line gefitinib in non-Asian patients with EGFR-mutated lung adenocarcinoma. Onkologie 2010; 33: 231-238. https:// doi.org/10.1159/000302729

[16] MIDHA A, DEARDEN S, MCCORMACK R. EGFR mutation incidence in non-small-cell lung cancer of adenocarcinoma histology: a systematic review and global map by ethnicity (mutMapII). Am J Cancer Res 2015; 5: 2892-2911.

[17] LEE JW, SOUNG YH, KIM SY, PARK WS, NAM SW et al. Absence of EGFR mutation in the kinase domain in common human cancers besides non-small cell lung cancer. Int J Cancer 2005; 113: 510-511. https://doi.org/10.1002/ ijc.20591

[18] SOKOLENKO AP, BOGDANOVA N, KLUZNIAK W, PREOBRAZHENSKAYA EV, KULIGINA ES et al. Double heterozygotes among breast cancer patients analyzed for BRCA1, CHEK2, ATM, NBN/NBS1, and BLM germ-line mutations. Breast Cancer Res Treat 2014; 145: 553-562. https://doi.org/10.1007/s10549-014-2971-1
[19] MERSCH J, JACKSON MA, PARK M, k M, NEBGEN D, PETERSON SK et al. Cancers associated with BRCA1 and BRCA2 mutations other than breast and ovarian. Cancer 2015; 121: 269-275. https://doi.org/10.1002/cncr.29041

[20] GORODNOVA TV, SOKOLENKO AP, IVANTSOV AO, IYEVLEVA AG, SUSPITSIN EN et al. High response rates to neoadjuvant platinum-based therapy in ovarian cancer patients carrying germ-line BRCA mutation. Cancer Lett 2015; 369: 363-367. https://doi.org/10.1016/j.canlet.2015.08.028

[21] MITIUSHKINA NV, IYEVLEVA AG, POLTORATSKIY AN, IVANTSOV AO, TOGO AV et al. Detection of EGFR mutations and EML4-ALK rearrangements in lung adenocarcinomas using archived cytological slides. Cancer Cytopathol 2013; 121: 370-376. https://doi.org/10.1002/cncy.21281

[22] YANUS GA, BELYAEVA AV, IVANTSOV AO, KULIGINA ESH, SUSPITSIN EN et al. Pattern of clinically relevant mutations in consecutive series of Russian colorectal cancer patients. Med Oncol 2013; 30: 686. https://doi.org/10.1007/ s12032-013-0686-5

[23] SOKOLENKO AP, ROZANOV ME, MITIUSHKINA NV, SHERINA NY, IYEVLEVA AG et al. Founder mutations in early-onset, familial and bilateral breast cancer patients from Russia. Fam Cancer 2007; 6: 281-286. https://doi. org/10.1007/s10689-007-9120-5

[24] ZHOU L, BABA Y, KITANO Y, MIYAKE K, ZHANG X et al. KRAS, BRAF, and PIK3CA mutations, and patient prognosis in 126 pancreatic cancers: pyrosequencing technology and literature review. Med Oncol 2016; 33: 32. https://doi. org/10.1007/s12032-016-0745-9

[25] GRECO FA, SPIGEL DR, YARDLEY DA, ERLANDER MG, MA XJ et al. Molecular profiling in unknown primary cancer: accuracy of tissue of origin prediction. Oncologist 2010; 15: 500-506. https://doi.org/10.1634/theoncologist.2009-0328

[26] SUSPITSIN EN, SOKOLENKO AP, VOSKRESENSKIY DA, IVANTSOV AO, SHELEHOVA KV et al. Mixed epithelial/ mesenchymal metaplastic carcinoma (carcinosarcoma) of the breast in BRCA1 carrier. Breast Cancer 2011; 18: 137140. https://doi.org/10.1007/s12282-009-0105-0

[27] DESOUKI MM, LIOYD J, XU H, CAO D, BARNER R et al. CDX2 may be a useful marker to distinguish primary ovarian carcinoid from gastrointestinal metastatic carcinoids to the ovary. Hum Pathol 2013; 44: 2536-2541. https://doi. org/10.1016/j.humpath.2013.06.014

[28] STRICKLAND-MARMOL LB, KHOOR A, LIVINGSTON SK, ROJIANI A. Utility of tissue-specific transcription factors thyroid transcription factor 1 and $\mathrm{Cdx} 2$ in determining the primary site of metastatic adenocarcinomas to the brain. Arch Pathol Lab Med 2013; 131: 1686-1690.

[29] PANARELLI NC, YANTISS RK, YEH MM, LIU Y, CHEN YT. Tissue-specific cadherin CDH17 is a useful marker of gastrointestinal adenocarcinomas with higher sensitivity than CDX2. Am J Clin Pathol 2012; 138: 211-222. https:// doi.org/10.1309/AJCPKSHXI3XEHW1J

[30] PARK JH, SEOL JA, CHOI HJ, ROH YH, CHOI PJ et al. Comparison of cadherin-17 expression between primary colorectal adenocarcinomas and their corresponding metastases: the possibility of a diagnostic marker for detecting the primary site of metastatic tumour. Histopathology 2011; 58: 315-318. https://doi.org/10.1111/j.1365-2559.2011.03746.x 
[31] TALANTOV D, BADEN J, JATKOE T, HAHN K, YU J et al. A quantitative reverse transcriptase-polymerase chain reaction assay to identify metastatic carcinoma tissue of origin. J Mol Diagn 2006; 8: 320-329. https://doi.org/10.2353/ jmoldx.2006.050136

[32] YAN Z, GIDLEY J, HORTON D, ROBERSON J, ELTOUM IE et al. Diagnostic utility of mammaglobin and GCDFP-15 in the identification of metastatic breast carcinoma in fluid specimens. Diagn Cytopathol 2009; 37: 475-478. https://doi. org/10.1002/dc.21039

[33] ZAFRAKAS M, PETSCHKE B, DONNER A, FRITZSCHE F, KRISTIANSEN $G$ et al. Expression analysis of mammaglobin A (SCGB2A2) and lipophilin B (SCGB1D2) in more than 300 human tumors and matching normal tissues reveals their co-expression in gynecologic malignancies. BMC Cancer 2006; 6: 88. https://doi.org/10.1186/1471-2407-6-88

[34] MIKHITARIAN K, GILLANDERS WE, ALMEIDA JS, HEBERT MARTIN R, VARELA JC et al. An innovative microarray strategy identities informative molecular markers for the detection of micrometastatic breast cancer. Clin Cancer Res 2005; 11: 3697-3704. https://doi.org/10.1158/1078-0432. CCR-04-2164
[35] BAKIR K, KOÇER NE, DENIZ H, GÜLDÜR ME. TTF-1 and surfactant- $\mathrm{B}$ as co-adjuvants in the diagnosis of lung adenocarcinoma and pleural mesothelioma. Ann Diagn Pathol 2004; 8: 337-341.

[36] KUROTANI R, KUMAKI N, NAIZHEN X, WARD JM, LINNOILA RI et al. Secretoglobin 3A2/uteroglobin-related protein 1 is a novel marker for pulmonary carcinoma in mice and humans. Lung Cancer 2011; 71: 42-48. https://doi. org/10.1016/j.lungcan.2010.04.001

[37] MOISEYENKO VM, VOLKOV NM, SUSPITSIN EN, YANUS GA, IYEVLEVA AG et al. Evidence for predictive role of BRCA1 and bTUBIII in gastric cancer. Med Oncol 2013; 30: 545. https://doi.org/10.1007/s12032-013-0545-4

[38] BENDER RA, ERLANDER MG. Molecular classification of unknown primary cancer. Semin Oncol 2009; 36: 38-43. https://doi.org/10.1053/j.seminoncol.2008.10.002

[39] MONZON FA, DUMUR CI. Diagnosis of uncertain primary tumors with the Pathwork tissue-of-origin test. Expert Rev Mol Diagn 2010; 10: 17-25. https://doi.org/10.1586/ erm.09.75 